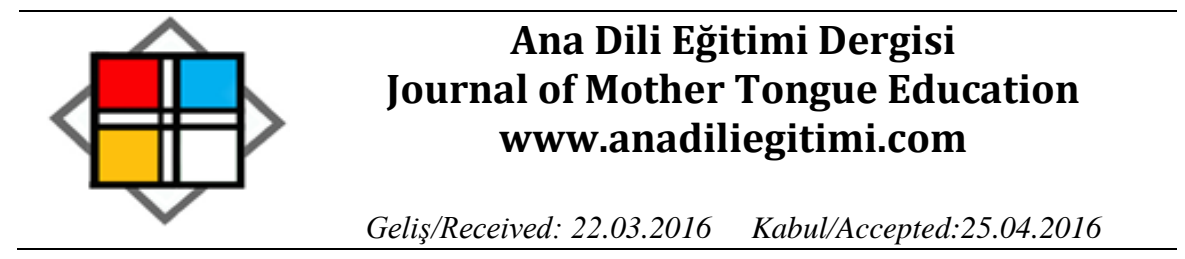

\title{
Eğitim Bilimleri Alanındaki Lisansüstü Tez Başlıklarının Kelime Sayısı ve Söz Dizimi \\ Bakımından İncelenmesi*
}

\author{
Kemalettin DENIZ** \\ Efecan KARAGÖL***
}

\begin{abstract}
Öz
Türkiye'de Eğitim Bilimleri Enstitüsünde Yükseköğretim Kurulunun belirlediği 43 alan vardır. Eğitim Bilimleri Enstitülerine bağlı farklı bölümlerde yapılan yüksek lisans ve doktora çalışmaları, tez adıyla bilimsel bir eser olarak ortaya konulmaktadır. Bu tezlerin yazım ölçütleri enstitülerce hazırlanan kılavuzlarla belirlenmektedir. Ancak tez başlıklarının ve söz dizimlerin nasıl olacağı konusunda farklı enstitülerce veya aynı enstitünün değişik zamanlarda hazırladığı kılavuzlarda bir birliğe varılmadığı görülmektedir. Bu çalışmada, eğitim bilimleri alanında yazıımış lisansüstü tez başlıkları kelime sayısı ve söz dizimi bakımından incelenmiştir. Bu amaçla YÖK Tez Tarama genel ağ sayfasında yapılan tarama sonucu, belirtilen alanlarda 2010-2015 yıllarında yazılmış yüksek lisans ve doktora tezlerinden tesadüfi yolla seçilen ve alanlara göre eşit dağılımın sağlandığı 240 başlık doküman analizi kullanılarak incelenmiştir. Çalışmada, tezlerin başlıklarının üç kelimeden yirmi yedi kelimeye kadar değiştiği, dolayısıyla başlık yazımında bir standart olmadığı tespit edilmiştir. Ayrıca başlıklarda, söz diziminin önemli unsurları olan tamlama ve bağdaşıklık unsurları açısından da sıkıntıların olduğu belirlenmiştir.
\end{abstract}

Anahtar Sözcükler: Başlık, Kelime sayısı, Söz dizimi, Eğitim bilimleri, Tez.

\section{Investigation of Postgraduate Titles Word Count and Syntax in the Field of Educational Sciences}

\begin{abstract}
There are 43 areas determined by the council of higher education at the graduate school of educational sciences in Turkey. The master's and doctoral studies which realized in different departments connected to educational sciences institutes reveals a scientific work known as thesis. Writing extent of this thesis are determined with guidelines prepared by the institutes. However the status of the thesis titles and syntax is unclear at the guidelines prepared by different institutes or at guidelines prepared at different times by the same institutes. In this study, postgraduate thesis titles in the field of educational sciences have been examined with regard to number of words and syntax. For this purpose, with the result of the scanning conducted at the YÖK browsing thesis public network, 240 master's and doctoral thesis titles were examined by using document
\end{abstract}

\footnotetext{
* Bu çalışma, 1-3 Ekim 2015 tarihleri arasında İstanbul Üniversitesinde düzenlenen 8. Uluslararası Türkçenin Eğitimi-Öğretimi Kurultayı'nda sunulan bildirinin genişletilmiş hâlidir.

** Doç. Dr., Gazi Üniversitesi, Gazi Eğitim Fakültesi Türkçe Eğitimi Bölümü, Ankara, Türkiye.

E-posta: kemalettindeniz@hotmail.com

*** Gazi Üniversitesi, Eğitim Bilimleri Enstitüsü Doktora Öğrencisi, Zonguldak, Türkiye.

E-posta: efecankaragol@gmail.com
} 
analysis which selected randomly and provided the equal distribution according to the fields written in 2010-2015 at specified areas. In this study, it was identified that the thesis titles changes from three words to twenty seven words so there isn't any standart title writing. Also it is noticed that there are some troubles in terms of phrases and elements of cohesion that are important elements of syntax.

Keywords: Title, Word count, Syntax, Educational sciences, Thesis.

\section{Giriş}

Türkiye'deki üniversitelerde bilimsel faaliyet gösterilen alanlardan biri Eğitim Bilimleri ve Öğretmen Yetiştirme Temel Alanıdır. Bu alanlara yönelik olarak üniversitelerin eğitim bilimleri enstitülerine bağlı farklı bölümlerde yüksek lisans ve doktora araştırmaları yapılmaktadır. Çalışmalar, tez adıyla bilimsel bir eser olarak ortaya konulmaktadır. Bu tezlerin yazım ölçütleri enstitülerce belirlenmektedir. Tez başlıklarının kaç kelime olacağı konusunda enstitülerce bir birliğe varılmamıştır. Başlığın söz dizimi açısından nasıl şekilleneceği ise hiç ortaya konulmamış bir konudur. Başıkların kelime sayısı ve söz dizimi açısından incelenmesi, bu belirsizliğin ortadan kaldııılmasına yardımcı olacaktır.

Eğitim bilimleri enstitülerinde, eğitim bilimleri ve öğretmen yetiştirme temel alanında lisansüstü eğitim yapılan ana bilim dalları şunlardır: Alman Dili Eğitimi, Arap Dili Eğitimi, Beden Eğitimi ve Spor Eğitimi, Bilgisayar ve Öğretim Teknolojileri Eğitimi, Biyoloji Eğitimi, Coğrafya Eğitimi, Çok Engellilerin Eğitimi, Din Kültürü ve Ahlak Bilgisi Eğitimi, Eğitim Felsefesi, Eğitim Programları ve Öğretimi, Eğitim Psikolojisi, Eğitim Sosyolojisi, Eğitim Tarihi, Eğitim Yönetimi, Teftişi, Planlaması ve Ekonomisi, Eğitimde Ölçme ve Değerlendirme, Felsefe Grubu Eğitimi, Fen Bilgisi Eğitimi, Fizik Eğitimi, Fransız Dili Eğitimi, Görme Engelliler Eğitimi, İngiliz Dili Eğitimi, İşitme Engelliler Eğitimi, Japon Dili Eğitimi, Kimya Eğitimi, Konuşma Engelliler Eğitimi, Ortaöğretim Matematik Eğitimi, Müzik Eğitimi, Okul Öncesi Eğitimi, Özel Eğitim, Rehberlik ve Psikolojik Danışmanlık, Resim İş Eğitimi, Tarih Eğitimi, Türk Dili ve Edebiyatı Eğitimi, Türkçe Eğitimi, Üstün Zekâlılar Eğitimi, Yetişkinler Eğitimi/Halk Eğitimi, Zihinsel Engelliler Eğitimi, Illköğretim Fen Bilgisi Eğitimi, İlköğretim Matematik Eğitimi, İlköğretim Sosyal Bilgiler Eğitimi, Sınıf Öğretmenliği Eğitimi, Aile Kaynakları Eğitimi, Din Eğitimi. YÖK'te “Eğitim Bilimleri ve Öğretmen Yetiştirme Temel Alanı" olarak adlandırılan bu bölümler üniversitelerde genellikle "Eğitim Bilimleri" adıyla yer alarak tek çatı altında toplanır. Bu sebeple araştırmada da eğitim bilimleri ifadesi kullanılmıştır.

Eğitim bilimleri alanında faaliyet gösteren bilim dallarının yüksek lisans ve doktora programlarında öğrencinin bilim uzmanı veya doktora unvanı alabilmesi için bilimsel bir araştırma yapması gerekmektedir. Araştırma, "konusu, amacı, kapsamı, süresi, özel şartları, bütçesi belirlenmiş; yeni bilgiler üretilmesi ve bilimsel yorumlarının yapılması veya teknolojik/sosyal problemlerin 
çözümlenmesi için bilimsel esaslara uygun olarak gerçekleştirilen çalışma" (TÜBITAK, 2009) demektir. Araştırmalar, bir rapor mahiyetinde olup genellikle tez olarak adlandırılırlar. Tez yazımında araştırmacılar tarafından oluşturulması gereken bazı bölümler vardır. Bunlar; başlık, özet, anahtar kelimeler, giriş, yöntem, bulgu ve yorumlar, sonuçlar, öneriler ve kaynakça kısımlarıdır. Bu bölümlerin nasıl şekillenmesi gerektiğine, üniversite enstitülerinin tez yazım kılavuzlarında temas edilmektedir.

Başlık, okuyucunun araştırmaya dair bilgi edinebileceği ilk bilgi kaynağıdır. Dolayısıyla bir tezin başığı, o çalışmanın içeriğine dair özetleyici bilgi vereceği için çalışmaya başlık belirlemek önemli bir basamaktır. Başlık, yazının ismidir. Yazılacak düşüncelerin esasını gösteren kelime veya kelime gurubudur. Bir yazıda mutlaka başlık bulunmalıdır. Başıık konu ile karıştııılmamalıdır. Başlık konunun anlaşılıp anlaşımadığını ve konunun sınırlarını da belirler. İyi bir başlık kısa, dikkat çekici ve ilgi uyandırıcı olmalıdır (Deniz, 2000: 121). Başlık konusunda dikkat çeken bir çalışma Yıldız (2000) tarafından yapılmıştır. Yıldız'ın gazete manşetleri üzerine yaptığı incelemede, uzun manşetlerin daha çok bilgi verdiği, kısa manşetlerin ise daha çok etkilemeye yönelik olduğu sonucuna varılmıştır (Yıldız, 2000: 112).

Araştırmanın başlığı çok sayıda kişi tarafından okunmaktadır. Çalışmanın tamamını okuyan kişi sayısı az olduğu için başlıktaki kelimeler çok dikkatli seçilmelidir. Yanlış yazıımış başlıklardaki en yaygın ve anlam bakımından en zarar verici durum, kelimelerin hatalı sıralanmasıdır. Bu sebeple kelimelerin birbiri ile ilişkileri dikkatle belirlenmelidir (Day, 2000: 11). Bunun yanı sıra başlıklar, o yazıda işlenilecek fikrin izlerini taşır; yazanı işlenilecek konudan uzaklaştırmamaya, o konuya bağlamaya yarar. Başlık, işlenilen fikre uygun olduğu takdirde, yazının bütününü daha etkili ve anlamlı hâle getirir (Tansel, 1978: 6). Başlığın bahsedilen nitelikleri taşıyabilmesi için başııtaki kelime sayısı ve söz dizimi önemli bir etken olarak öne çıkmaktadır.

Tez başlıklarının dikkat çekebilme açısından genel olarak kısa ve öz olması gerekmektedir. Başııta az sayıda kelime ile anlatım, daha etkili olmaktadır. Türkiye'deki üniversitelerin çoğu, tez yazım kılavuzlarını Amerika Psikoloji Birliği'nin (American Psychological Association / APA) sistemine uygun olarak düzenler. Tez başlıklarının kaç kelime olması gerektiğine bazı üniversitelerin tez yazım kılavuzunda yer verilirken bazılarında kelime sayısı belirtilmemiştir.

Tablo 1. Eğitim bilimleri enstitülerince yayımlanan tez yazım kılavuzlarındaki başlık kelime sayısı kuralları

\begin{tabular}{lll}
\hline & \multicolumn{1}{c}{ Üniversite Adı } & \multicolumn{1}{c}{ Tez Başlığındaki Kelime Sayısı } \\
\hline 1. & $\begin{array}{l}\text { Abant İzzet Baysal } \\
\text { Üniversitesi }\end{array}$ & Bağlaçlar dâhil 16 kelimeyi geçmemeli. \\
2. & Akdeniz Üniversitesi & Tezin başlığı 15-20 kelimeyi geçmemeli. \\
3. & Anadolu Üniversitesi & $\begin{array}{l}\text { Genellikle iyi bir tez başlığının } 12 \text { sözcükten fazla olmaması } \\
\text { önerilmektedir. }\end{array}$ \\
\hline
\end{tabular}




\begin{tabular}{|c|c|c|}
\hline 4. & Ankara Üniversitesi & 15 sözcüğü geçmemeli. \\
\hline 5. & Atatürk Üniversitesi & Tezin başlığı 15-20 kelimeyi geçmemeli. \\
\hline 6. & Bartın Üniversitesi & $\begin{array}{l}\text { Tezin başlığı ideal olarak 13-15 kelimeyi geçmemeli; ancak gerekli } \\
\text { durumlarda } 26 \text { kelimeye kadar kabul edilebilir. }\end{array}$ \\
\hline 7. & $\begin{array}{l}\text { Çanakkale Onsekiz Mart } \\
\text { Üniversitesi }\end{array}$ & 20 kelimeyi geçmemeli. \\
\hline 8. & Dokuz Eylül Üniversitesi & Belirtilmemiştir. \\
\hline 9. & Gazi Üniversitesi & Belirtilmemiştir. \\
\hline 10. & Hacettepe Üniversitesi & $\begin{array}{l}\text { Tez çalışmalarında (tümü büyük harflerle yazılan) başlık en fazla } 15 \\
\text { sözcük olmalı ve kısaltma kullanılmamalıdır. }\end{array}$ \\
\hline 11. & İstanbul Üniversitesi & Belirtilmemiştir. \\
\hline 12. & Karadeniz Teknik Üniversitesi & $\begin{array}{l}\text { Başlığın çok uzun ve anlaşııması güç genel terimlerden oluşmamasına } \\
\text { dikkat edilmelidir. }\end{array}$ \\
\hline 13. & Marmara Üniversitesi & Belirtilmemiştir. \\
\hline 14. & On Dokuz Mayıs Üniversitesi & $\begin{array}{l}\text { Çok uzun, anlaşııması güç ve çok genel tez adlarından kaçınılmalı, } \\
\text { gerekirse teze alt başlık konulmalıdır. }\end{array}$ \\
\hline 15. & Uludağ Üniversitesi & Tezin başlığı 15-20 kelimeyi geçmemeli. \\
\hline
\end{tabular}

Yukarıdaki tabloya bakıldığında üniversitelerin eğitim bilimleri enstitüleri arasında tez başııklarının kelime sayılarında farklılıklar olduğu görülmektedir. Bazı enstitüler üst sınır belirtirken bazıları aralık belirtmekte, bazıları ise bu konuda bir bilgiye yer vermemektedirler. Dolayısıyla tez başıklarının kelime sayılarına dair bir standart yoktur. Bu durum yazılan tezlerdeki başlık tercihlerinin incelenmesini gerekli kılmaktadır.

Kısa ve çarpıcı başlık yazmada önemli olan etkenlerden biri de söz dizimidir. Söz dizimi; cümle bilgisi, sentaks veya nahiv olarak da bilinir. Söz dizimi, "Bir dilde düşünce ve duyguların tam olarak anlatılabilmesi için gramer kurallarına uygun olarak dizilen kelimelerin, kelime gruplarının cümle ve söz içindeki görevlerini, birbiriyle olan ilişkilerini, sıralanışlarını ve cümle türlerini inceleyen bilim dalıdır." (Korkmaz, 2007: 55). Tez başlıkları da kelime gruplarından oluştuğu için doğal olarak söz diziminin kurallarına uymak durumundadır. Başlıkların söz dizimlerinde, kullanılan tamlamalar ve bağdaşıklık unsurları önemli etkenlerdir.

Tamlama, bir ismin anlamını daha ayrıntılı olarak belirleyebilmek amacıyla o ismin tamlayan görevindeki isim veya isim soylu sıfat, zamir gibi başka bir kelime ile tamamlanması olarak ifade edilir. Tamlamalar, bir tamlayanla bir tamlananın oluşturduğu kelime gruplarıdır (Korkmaz, 2007: 207). Tamlayan, tamlamanın birinci ögesini oluştururken tamlanan ikinci ögeyi oluşturur.

Bağdaşıklık, metindeki kelime ve cümlelerin bir silsile hâlinde, birbirlerine bağlanma durumlarını ele alır. Bağdaşıklık, söylemde bir ögenin yorumunun bir başka ögeye bağlı olarak yapıldığı durumları ifade eder (Coşkun, 2005: 45). Bağdaşıklığı oluşturan unsurlar şunlardır: gönderim, eksiltili anlatım, değiştirim, bağlama ögeleri ve kelime bağdaşıklığı. 
Tamlama ve bağdaşıklık unsurları başlıkların söz dizimlerinde önemli birer etken olmalarına rağmen tez yazım kılavuzlarında bu konuda net ifadeler bulunmamaktadır. Bunun yerine "tezlerin yazımında Türkçe yazım kurallarına uyulmalıdır. Bu amaçla Türk Dil Kurumu'nun (TDK) yazım kılavuzu rehber alınmalıdır. (...) Tezlerde, kullanılan dilin kurallarına uygun, açık ve anlaşılır bir anlatım tercih edilmelidir (Gazi, 2014: 6)." gibi açıklamalara yer verilmiştir.

"Tez", "başık" ve "kelime sayısı" anahtar kelimeleriyle "YÖK Tez Tarama" ve "Dergipark"ta yapılan taramada sadece Sevim ve Eren (2012) tarafından yapılan "Türkçe Eğitimi Alanındaki Yüksek Lisans Tezlerinin Başlıklarına ve Özetlerine Eleştirel Bir Bakış" adlı çalışma tespit edilmiştir. Bu çalışmada, Türkçe eğitimi alanındaki yüksek lisans tezlerinin başlık ve özetleri incelenmiştir. Araştırmanın sonunda, yüksek lisans tez başlıklarının \%43,8'inin (11-15 sözcük) bilim dünyası tarafından genel kabul görmüş ölçütlere uygun olduğu sonucuna varılmıştır. Eğitim bilimleri alanında yazıımış tezlerin başlıkları, söz dizimi ve kelime sayısı bakımından incelemeye tabi tutulmamıştır.

Bu çalışmanın amacı, Eğitim bilimleri alanında yazılmış lisansüstü tez başıklarını söz dizimi ve kelime sayısı bakımından incelemektir. Bu amaca yönelik daha ayrıntılı bilgiye ulaşabilmek için aşağıdaki alt problemlerden yararlanılmıştır:

1. Eğitim bilimleri alanında yazıımış lisansüstü tez başlıklarının kelime sayısı bakımından durumu nedir?

2. Eğitim bilimleri alanında yazıımış lisansüstü tez başlıklarının söz dizimi bakımından durumu nedir?

Araştırma, eğitim bilimleri alanında yazıımış lisansüstü tez başlıklarının kelime sayısı ve söz dizimlerini incelemesi ve başlık belirlemede var olan belirsizliğin ortadan kaldırılmasına yardımcı olması açısından önemlidir. Çalışma, 2010 yılı ve sonrasında yazılan lisansüstü tezleriyle sınırlandırılmıştır.

\section{Yöntem}

\section{Araştırmanın Modeli}

Araştırma, nitel araştırma modeline göre tasarlanmıştır. Nitel araştırmalarda kullanılan tarama modeliyle yapılan bir çalışmada "Araştırmaya konu olan olay, birey ya da nesne, kendi koşulları içinde ve olduğu gibi tanımlanmaya çalışılır. Onları herhangi bir şekilde değiştirme, etkileme çabası gösterilmez. Bilinmek istenen şey vardır ve oradadır. Önemli olan, onu uygun biçimde gözleyip belirleyebilmektir." (Karasar, 2008: 77). Bu araştırma 2010 yılı ve sonrasında eğitim bilimleri alanında yazılmış lisansüstü tez başıklarını kelime sayısı ve söz dizimi bakımından incelemeyi amaçladığından betimsel araştırma yöntemlerinden tarama modeli kullanılmıştır. 
Betimsel araştırmalarda araştırmacı, belli bir konuyla ilgili bulguları ortaya çıkarmak için gerekli çalışmaları yapar. Bu maksatla 2010 yılı ve sonrasında yazılmış lisansüstü tez başlıkları doküman analizi kullanılarak incelenmiştir. Doküman analizi, çalışmada kullanılacak dokümanların elde edilip belirli bir sistem içerisinde inceleme işlemidir (Karasar, 2008; Yıldırım ve Şimşek, 2011).

\section{Evren ve Örneklem}

Araştırmanın evrenini eğitim bilimleri ve öğretmen yetiştirme temel alanlarında yazılan tezlerin başlıkları oluşturmaktadır. Örneklemi ise YÖK Tez Tarama genel ağ sayfasında yapılan tarama sonucu bu alanlarda 2010-2015 yıllarında yazılmış yüksek lisans ve doktora tezlerinden tesadüfi yolla seçilen ve alanlara göre eşit dağılımın sağlandığı 240 başlık oluşturmaktadır.

\section{Verilerin Toplanması ve Çözümlenmesi}

Araştırmanın temel veri kaynakları 2010 yılı ve sonrasında eğitim bilimleri alanında yazılmıs lisansüstü tezlerinin başlıklarıdır. YÖK Tez Tarama (https://tez.yok.gov.tr/ UlusalTezMerkezi/ tarama.jsp) adresinde şu alanlara yönelik tezler taranmıştır: Alman Dili Eğitimi, Arap Dili Eğitimi, Beden Eğitimi ve Spor Eğitimi, Bilgisayar ve Öğretim Teknolojileri Eğitimi, Biyoloji Eğitimi, Coğrafya Eğitimi, Çok Engellilerin Eğitimi, Din Kültürü ve Ahlak Bilgisi Eğitimi, Eğitim Felsefesi, Eğitim Programları ve Öğretimi, Eğitim Psikolojisi, Eğitim Sosyolojisi, Eğitim Tarihi, Eğitim Yönetimi, Teftişi, Planlaması ve Ekonomisi, Eğitimde Ölçme ve Değerlendirme, Felsefe Grubu Eğitimi, Fen Bilgisi Eğitimi, Fizik Eğitimi, Fransız Dili Eğitimi, Görme Engelliler Eğitimi, İngiliz Dili Eğitimi, İşitme Engelliler Eğitimi, Japon Dili Eğitimi, Kimya Eğitimi, Konuşma Engelliler Eğitimi, Ortaöğretim Matematik Eğitimi, Müzik Eğitimi, Okul Öncesi Eğitimi, Özel Eğitim, Rehberlik ve Psikolojik Danışmanlık, Resim İş Eğitimi, Tarih Eğitimi, Türk Dili ve Edebiyatı Eğitimi, Türkçe Eğitimi, Üstün Zekâlılar Eğitimi, Yetişkinler Eğitimi/Halk Eğitimi, Zihinsel Engelliler Eğitimi, illköğretim Fen Bilgisi Eğitimi, İlköğretim Matematik Eğitimi, İlköğretim Sosyal Bilgiler Eğitimi, Sınıf Öğretmenliği Eğitimi, Aile Kaynakları Eğitimi, Din Eğitimi. Eğitim Taramada yüksek lisans ve doktora düzeylerinde "Çok Engellilerin Eğitimi", "Eğitim Sosyolojisi", "Eğitim Tarihi", "Japon Dili Eğitimi", "Konuşma Engelliler Eğitimi", "Yetişkinler Eğitimi/Halk Eğitimi" ve "Aile Kaynakları Eğitimi" adıyla alan olmadığı belirlenmiştir. Ayrıca yüksek lisans düzeyinde "Ortaöğretim Matematik Eğitimi" ve "Din Eğitimi" alanlarında; doktora düzeyinde ise "Arap Dili ve Eğitimi", "Din Kültürü ve Ahlak Bilgisi Eğitimi", "Eğitim Felsefesi", "Felsefe Grubu Eğitimi", "Din Eğitimi" alanlarında tez çalışması tespit edilememiştir. Dolayısıyla yüksek lisans düzeyinde 34 alandan, doktora düzeyinde ise 31 alandan veri toplanmıştır. Veri toplama işleminde, yapılan taramada çıkan tez sayıları 10'dan az ise baştan 1. ve 2., sondan 1. ve 2. sıradaki tezler; 10 'dan fazla ise baştan 3. ve 4., sondan 5. ve 6. sıradaki tezler seçilmiştir. Araştırmaya dâhil edilen tezlerin lisansüstü düzeylere göre dağılımı frekans ve yüzde dağııımıyla Tablo 2'de sunulmuştur: 
Tablo 2. Tezlerin lisansüstü düzeye göre dağılımı

\begin{tabular}{ccc}
\hline Tez Türü & Frekans & Yüzde (\%) \\
\hline Yüksek Lisans & 128 & 53,3 \\
Doktora & 112 & 46,7 \\
Toplam & 240 & 100,0 \\
\hline
\end{tabular}

Toplamda yüksek lisans düzeyinde 128, doktora düzeyinde ise 112 tez araştırmada ele alınmıştır. Belirlenen tezlerin başlıklarındaki kelime sayıları, yüksek lisans ve doktora olmak üzere ayrı ayrı sayılmış ve bu başlıkların SPSS İstatistik 21.0 programıyla frekans ve yüzde dağılımları verilmiştir. Ayrıca bu başıklar, söz dizimini oluşturan tamlama ve bağdaşıklık unsurları açısından da incelenmiştir. Bunun için de başıklardaki isim tamlaması, sıfat tamlaması ve bağdaşıklığı oluşturan gönderim, eksiltili yapı, değiştirim, bağlama ögeleri, kelime bağdaşıklığı gibi unsurlar tespit edilerek elde edilen bulgular tablo hâlinde sunulmuştur.

\section{Bulgular}

Bu bölümde araştırma kapsamında incelenen yüksek lisans ve doktora tez başlıklarıyla ilgili elde edilen bulgulara yer verilmiştir.

\section{Kelime Sayısı Bakımından Tez Başlıkları}

Eğitim Bilimleri alanında yüksek lisans düzeyinde yazılan tez başlıklarının kelime sayısı dağılımı frekans ve yüzde analiziyle Tablo 3 'te sunulmuştur:

Tablo 3. Yüksek lisans tez başlıklarının kelime sayısı dağılımı

\begin{tabular}{|c|c|c|c|}
\hline & Kelime sayısı & Frekans & Yüzde (\%) \\
\hline 1. & 4 kelime & 2 & 1,6 \\
\hline 2. & 5 kelime & 3 & 2,3 \\
\hline 3. & 6 kelime & 6 & 4,7 \\
\hline 4. & 7 kelime & 6 & 4,7 \\
\hline 5. & 8 kelime & 8 & 6,3 \\
\hline 6. & 9 kelime & 11 & 8,6 \\
\hline 7. & 10 kelime & 10 & 7,8 \\
\hline 8. & 11 kelime & 8 & 6,3 \\
\hline 9. & 12 kelime & 9 & 7,0 \\
\hline 10. & 13 kelime & 12 & 9,4 \\
\hline 11. & 14 kelime & 10 & 7,8 \\
\hline 12. & 15 kelime & 9 & 7,0 \\
\hline 13. & 16 kelime & 10 & 7,8 \\
\hline 14. & 17 kelime & 5 & 3,9 \\
\hline 15. & 18 kelime & 10 & 7,8 \\
\hline 16. & 19 kelime & 2 & 1,6 \\
\hline 17. & 20 kelime & 3 & 2,3 \\
\hline 18. & 21 kelime & 1 & 8 \\
\hline 19. & 22 kelime & 1 & ,8 \\
\hline 20. & 26 kelime & 1 & 8 \\
\hline \multirow[t]{2}{*}{21.} & 27 kelime & 1 & 8 \\
\hline & Toplam & 128 & 100,0 \\
\hline
\end{tabular}


Yüksek lisans tez başlıklarındaki kelime sayısı 4 kelimeden $(\% 1,6) 27$ kelimeye $(\% 0,8)$ kadar dağılım göstermektedir. En çok tercih edilen tez başlığı kelime sayısının \%9,4 oranla 13 kelime olduğu görülmektedir. Bunu \%8,6 oranla 9 kelime takip etmektedir. Tabloya genel olarak bakıldığında 19 kelime üzerindeki tez başıklarının \%7,1 oranla oldukça az tercih edildiği sonucuna varılabilir. 8-18 kelime aralığına sahip başlık oranı \%79,7'dir.

Eğitim bilimleri alanında doktora düzeyinde yazılan tez başlıklarının kelime sayısı dağılımı frekans ve yüzde analiziyle Tablo 4 'te sunulmuştur:

Tablo 4. Doktora tez başlıklarının kelime sayısı dağılımı

\begin{tabular}{cccc}
\hline & Kelime sayısı & Frekans & Yüzde (\%) \\
\hline 1. & 3 kelime & 1 &, 9 \\
2. & 4 kelime & 1 &, 9 \\
3. & 5 kelime & 1 &, 9 \\
4. & 6 kelime & 3 & 2,7 \\
5. & 7 kelime & 3 & 2,7 \\
6. & 8 kelime & 8 & 7,1 \\
7. & 9 kelime & 10 & 8,9 \\
8. & 10 kelime & 8 & 7,1 \\
9. & 11 kelime & 12 & 10,7 \\
10. & 12 kelime & 6 & 5,4 \\
11. & 13 kelime & 8 & 7,1 \\
12. & 14 kelime & 6 & 5,4 \\
13. & 15 kelime & 15 & 13,4 \\
14. & 16 kelime & 7 & 6,3 \\
15. & 17 kelime & 5 & 4,5 \\
16. & 18 kelime & 8 & 7,1 \\
17. & 19 kelime & 6 & 5,4 \\
18. & 20 kelime & 1 &, 9 \\
19. & 22 kelime & 1 &, 9 \\
20. & 23 kelime & 1 &, 9 \\
21. & 24 kelime & 1 &, 9 \\
& Toplam & 112 & 100,0 \\
\hline
\end{tabular}

Tabloda görüldüğü gibi doktora tez başlıkları 3 kelimeden $(\% 0,9) 24$ kelimeye $(\% 0,9)$ kadar dağılım göstermektedir. En çok tercih edilen tez başlığı kelime sayısının \%13,4 oranla 15 kelime olduğu görülmektedir. Bunu \%10,7 oranla 11 kelime takip etmektedir. Tabloya genel olarak bakıldığında kısa (3-5 kelime aralığı) ve uzun (20 kelime ve üzeri) başlıkların az tercih edildiği sonucuna varılabilir. 8-18 kelime aralığına sahip başlık oranı \%83'tür.

\section{Söz Dizimi Bakımından Tez Başıkları}

Eğitim bilimleri alanında yazılmış lisansüstü tez başıklarında yer alan isim tamlamaları tablo 5'te sunulmuştur: 
Tablo 5. Tez başlıklarında yer alan tamlamalar

\begin{tabular}{ccccc}
\hline \multirow{2}{*}{ Tez Türü } & Ḃsim Tamlaması & & \\
& $\begin{array}{c}\text { Belirtili İsim } \\
\text { Tamlaması }\end{array}$ & $\begin{array}{c}\text { Belirtisiz İsim } \\
\text { Tamlaması }\end{array}$ & $\begin{array}{c}\text { Zincirleme İsim } \\
\text { Tamlaması }\end{array}$ & Sıfat Tamlaması \\
\hline Yüksek Lisans & 79 & 102 & 92 & 124 \\
Doktora & 107 & 54 & 48 & 122 \\
\hline
\end{tabular}

İncelenen yüksek lisans tezlerinin başlıklarında 79 belirtili isim tamlaması, 102 belirtisiz isim tamlaması, 92 zincirleme isim tamlaması ve 124 sıfat tamlaması yer almaktadır. Doktora tezlerinde ise 107 belirtili isim tamlaması, 54 belirtisiz isim tamlaması, 48 zincirleme isim tamlaması ve 122 sıfat tamlamasının yer aldığı görülmektedir.

Bazı tezlerin başlıklarında birden fazla isim tamlamasının kullanıldığı belirlenmiştir. Yüksek lisans tez başlıklarının 84'ünde, doktora tez başlıklarının ise 39'unda birden fazla isim tamlaması kullanılmıştır. Tezlerin başlıklarında birden fazla isim tamlamasının kullanılması başlığın doğal olarak uzun olmasına neden olmaktadır. Aşağıda birden fazla isim tamlaması kullanılan tez başıklarına örnekler verilmiştir:

1. Psikomotor hareket etkinliklerine katılımın saldırgan davranışlar üzerine etkilerinin anne, baba ve öğretmen görüşleri açısından incelenmesi

2. Müzik öğretmenliği ana bilim dalında öğrenim gören anadolu güzel sanatlar ve spor liseleri ile diğer lise mezunu öğrencilerin bireysel ses eğitimi dersindeki müzikal beceri farkıııklarının karşılaştırılması

3. Raven'ın ilerleyen matrisler plus testinin 14-15 yaş çocukları üzerinde geçerlik, güvenirlik ve ön norm çalışmalarına göre üstün olan ve üstün olmayan öğrencilerin duygusal zeka düzeylerinin karşılaştırılması

4. Dijital hikayecilik metoduyla hazırlanan öğretim materyallerinin öğrenme döngüsü giriş aşamasında kullanılmasının fizik dersi başarısı ve motivasyonu düzeyine etkisi

5. Ortaöğretim matematik öğretmen adaylarının tek ve iki değişkenli fonksiyonların limiti ve sürekliliği ile ilgili kavram bilgileri arasındaki ilişkilerin incelenmesi

6. Otistik spektrum bozukluğu tanısı almış çocukların ailelerine yönelik bir psiko-eğitsel grup programının ebeveynlerin bazı psikolojik değişkenleri üzerindeki etkisi

Tez başlıkları bağdaşıklık unsurları yönüyle de incelenmiştir. Bu unsurlar gönderim, değiştirim, bağlama ögeleri ve kelime olarak ele alınmıştır. 
Tablo 7. Tez başlıklarının bağdaşıklık açısından durumu

\begin{tabular}{|c|c|c|c|c|c|c|}
\hline & \multicolumn{2}{|c|}{ Gönderim } & \multirow[t]{2}{*}{ Eksiltili Yapı } & \multirow[t]{2}{*}{ Değiştirim } & \multirow{2}{*}{$\begin{array}{c}\text { Bağlama } \\
\text { Ögeleri }\end{array}$} & \multirow{2}{*}{$\begin{array}{c}\text { Kelime } \\
\text { Bağdaşıklığ }\end{array}$} \\
\hline & Ön & Art & & & & \\
\hline $\begin{array}{l}\text { Yüksek } \\
\text { Lisans }\end{array}$ & - & 5 & 28 & - & 80 & - \\
\hline Doktora & - & - & 18 & - & 99 & - \\
\hline
\end{tabular}

Yüksek lisans düzeyinde yazılan tezlerin başlıklarında 5 art gönderim, 28 eksiltili yapı ve 80 bağlama ögesi tespit edilmiştir. Doktora düzeyinde yazılan tezlerin başlıklarında ise 18 eksiltili yapı ve 99 bağlama ögesinin olduğu görülmektedir. Yüksek lisans ve doktora tezlerinin başlıklarında ön gönderim, değiştirim ve kelime bağdaşıklığına yer verilmemiştir.

Eksiltili yapılar, bilimsel metinlerde çok sık rastlanan bir yapı değildir. İncelenen yüksek lisans ve doktora tezlerinde eksiltili yapılar tespit edilmiştir. Eksiltili yapıların bulunduğu tez başıklarına örnekler:

1. Din kültürü ve ahlak bilgisi ders kitaplarında ahlak öğrenme alanında kullanılan hadisler ve eğitim-öğretim açısından değerlendirilmesi (4.-8. sınıflar)

2. Sınıf öğretmenlerinin sınıf yönetiminde karşılaştıkları disiplin sorunları, nedenleri ve bu sorunlarla baş etme yöntemlerinin değerlendirilmesi: Bingöl ili örneği

3. Sınıf öğretmenlerinin fen öğretimine yönelik tutumları ile öğrencilerinin fen başarıları arasındaki ilişkinin araştırılması (Sivas)

4. Almancanın yabancı dil olarak öğretilmesinde çocuk ve gençlik yazınının yeri ve öneminin okuma dersleri bağlamında irdelenmesi

5. Mekanik konularının öğretiminde yaratıcı drama yönteminin uygulanması ve değerlendirilmesi

6. İsitme engelli öğrenciler ve normal işiten öğrencilerin okuma becerilerinin formel olmayan okuma envanteri ile değerlendirilmesi

\section{Sonuç ve Tartışma}

Eğitim bilimleri alanında yazılan 128 yüksek lisans tezi ile 112 doktora tezinin başıkları kelime sayısı, bağdaşıklık ve tamlamalar açısından değerlendirilmiştir. Araştırmanın bulguları, yüksek lisans tezlerinin başlıklarında yer alan kelime sayısının 4 kelimeden 27 kelimeye kadar geniş bir aralıkta değiştiğini göstermektedir. Ancak 4, 5, 6 ve 19, 20, 21, 22, 26, 27 kelimeden oluşan yüksek lisans tez 
başııklarının toplamda \%8,6 ve \%7.1 oranlarında az kullanıldığı görülmektedir. Dolayısıyla çok kısa ve çok uzun olan başlıkların, yüksek lisans tez başlıklarında tercih edilmediği sonucuna varılabilir. Yüksek lisans tez başlıklarında en çok tercih edilen kelime sayısı \%9,4 oranla 13'tür. Bunu \%8,6 oranla 9 kelime takip etmektedir. Buradan hareketle eğitim bilimleri alanında yapılan yüksek lisans tezlerinde \%39,1 oranla 9-13 kelime aralığının en çok tercih edilen tez başlığı olduğu söylenebilir. Daha geniş bir aralık oluşturulmak istendiğinde ise 8-18 kelimenin \%79,7 oranında tercih edildiği görülmektedir.

Doktora tez başlıklarında yer alan kelime sayılarının 3 'ten 24 kelimeye kadar geniş bir aralıkta değiştiği tespit edilmiştir. 3, 4, 5, 6, 7 ve 20, 22, 23, 24 kelimeden oluşan doktora tezi başlıklarının toplamda \%8,1 ve \%3,6 oranlarında az kullanıldığı görülmektedir. Yüksek lisans tez başlıklarında olduğu gibi çok kısa ve çok uzun başlıkların tercih edilmediği sonucuna ulaşılabilir. Doktora tezi başlıklarında en çok tercih edilen kelime sayısı \%13,4 oranla 15 kelimedir. Bunu \%10,7 oranla 11 kelime takip etmektedir. Buradan hareketle Eğitim bilimleri alanında doktora düzeyinde yapılan tezlerin başıklarının \%42 oranla 11-15 kelime aralığında olduğu söylenebilir. Daha geniş bir aralıkta ise 8-18 kelimeye sahip başlık oranı \%83'tür.

Yüksek lisans ve doktora tezi başlıklarının çoğu enstitüde 13-15 kelime olarak belirlenmesi, okunabilirlik kavramıyla ilişkilendirilebilir. Okunabilirlik, bir metnin kolay veya güç anlaşılabilir olmasını karşılayan kavramdır. Okunabilirlikle ilgili çeşitli araştırmalar yapılmıştır (Ateşman, 1997, Çetinkaya, 2010, Durukan, 2014, Karatay vd. 2013, Temur, 2003). Klare ve Rye tarafından ortaya konulan okunabilirliği etkileyen etmenler arasında "söz dizimi" ve "cümle uzunluğu" kavramları da vardır (Çetinkaya, 2010: 12). Bu kavramlar, lisansüstü tez başlıklarındaki kelime sayısı meselesiyle de yakından ilgilidir. Zira, Durukan (2014) tarafından yapılan bir araştırmaya göre metinlerin kelime ve cümle uzunluklarının artması öğrencilerin okuma hızlarını ve okuduğunu anlama düzeylerini olumsuz etkilemektedir. Dolayısıyla yüksek lisans ve doktora tez başlıklarındaki kelime sayısı her ne kadar geniş yelpazede seyretse de ağırlıklı oranın orta kesimlerde olması, tez başlıklarını belirlemede okunabilir ve anlaşılabilir olma durumunun göz önünde bulundurulmasıyla ilgili olabilir. Ayrıca en çok tercih edilmesi bakımından yüksek lisansta 13 olan tez başıkları kelime sayısının doktorada 15 kelimeye çıkması akademik seviyenin artmasıyla açıklanabilir.

Araştırma bulguları, eğitim bilimleri alanında yazılan yüksek lisans tez başlıklarında 397 tamlama kullanıldığını göstermektedir. Bunlardan 79'u belirtili isim tamlaması, 102'si belirtisiz isim tamlaması, 92'si zincirleme isim tamlaması ve 124'ü sıfat tamlamasıdır. Doktora tezlerinde ise 331 adet tamlama kullanılmıştır. Bunlardan 107'si belirtili isim tamlaması, 54'ü belirtisiz isim tamlaması, 48'i zincirleme isim tamlaması ve 122 'si sıfat tamlamasıdır. Birden fazla isim tamlaması ile oluşturulan yüksek lisans tez başlıkları 84, doktora tez başlıkları 39 adettir. Bir başlığın teşekkülünde isim tamlamalarının sık kullanımı başlıktaki kelime sayısının artmasına, başlığın uzun olmasına ve dolayısıyla okunabilirlik ve anlaşılabilirlik hususunda sıkıntılı olmasına sebebiyet vermektedir. Bulgulara göre 
dikkat çeken bir husus da birden fazla isim tamlaması kullanılan tez başlıklarının doktora düzeyinde yüksek lisans düzeyine göre yarı yarıya azalmış olmasıdır. Bu durum doktora tez başlıklarının daha okunabilir ve anlaşılabilir olmasını sağlamaktadır.

Bağdaşıklık unsurları açısından yüksek lisans tez başlıklarında 5 art gönderim, 28 eksiltili yapı ve 80 bağlama ögesi tespit edilmiştir. Ön gönderim, değiştirim ve kelime bağdaşıklığına rastlanmamıştır. Doktora tezlerinde ise 4 eksiltili yapı ve 99 bağlama ögesi belirlenmiştir. Ön ve art gönderim, değiştirim ve kelime bağdaşıklığına incelenen doktora tezlerinin başlıklarında rastlanamamıştır.

Eksiltili anlatım, anlam kaybına yol açmamak koşulu ile bir cümle içinden zamanla bazı sözcükleri atma işidir ya da kullanılmayışları anlatımda eksikliğe yol açmayan sözcüklerin düşürülmesidir (Günay, 2001: 64). Bilimsel bir metin olan tezlerde eksiltili yapıların kullanımı bazı durumlarda bilimselliğin doğasına aykırı olabilmektedir. Bazı tez başıklarında eksiltili yapının kullanııması bağdaşıklığı bozmakta ve ifadenin akıcı olmasını engellemektedir. Eksiltili yapılara örnek olarak verilen "Din kültürü ve ahlak bilgisi ders kitaplarında ahlak öğrenme alanında kullanılan hadisler ve eğitim-öğretim açısından değerlendirilmesi (4.-8. sınıflar)" başlığı eksiltili yapının yanlış kullanımı açısından bir örnek teşkil edebilir. Bu örnekte "ve" bağlacından sonra kullanılmayan "hadislerin" kelimesinin bağdaşıklığın bozulmasına yol açtığı söylenebilir. Dolayısıyla bir tez başlı̆ında kullanılmayışı anlatımda eksikliğe yol açmadığı düşünülen ifadelerin çıkarılması hususunda dikkat edilmelidir. Sonuçlardan hareketle buna benzer başka önerilerin de sunulması mümkündür.

Türkiye'de eğitim bilimleri alanındaki yüksek lisans ve doktora tezlerinin başlıklarında kelime sayısı ve sözdizimi açısından farklılıkların, kuralsızlıkların ve anlatım bozukluklarının olduğu sonucuna ulaşılmıştır. Bu sorunların giderilmesi için öncelikle her enstitünün tez yazım kılavuzunda başıkların kelime sayısı aralığı net bir şekilde belirtilmelidir. Bu aralığın belirlenmesinde okunabilirlik ve alanlara uygunluk ölçütü dikkate alınmalıdır. Dolayısıyla dikkat dağıtan ve anlamayı zorlaştıran uzun başıklardan ve tez hakkında yeterince bilgi vermeyen kısa başlıklardan kaçınılmalıdır.

Tez yazım kılavuzlarında başlıklardaki tamlamaların kullanımı hususunda da açıklamaya yer verilmelidir. Özellikle isim tamlamalarının iç içe kullanıldığı zincirleme isim tamlamaları ve birden fazla isim tamlamasının kullanıldığı başlıklar akıcılıktan uzaklaşmaktadır. Bu da başlığın okunabilirliğini ve anlaşılabilirliğini olumsuz yönde etkilemektedir.

Söz diziminde tamlamalardan sonra kullanılan önemli bir unsur da bağdaşıklıktır. Başlıklarda ön gönderim yapılmamasına dikkat edilmelidir. Ayrıca eksiltili yapıların yanlış kullanımı anlatım bozukluğuna yol açtığından eksiltili yapı kullanımında hassas olunmalıdır. Tezlerde rastlanan söz dizimi hatalarının giderilmesi için tez yazım kılavuzlarına söz dizimiyle ilgili bölüm konulmalıdır. Bunun yanı sıra farklı enstitülerin farklı ana bilim dallarında yapılan tez çalışmalarının raporlama sürecinin bitiminden önce bir dil uzmanının kontrolünden geçmesi zorunluluğu getirilmelidir. 
Tez yazımında okuyucunun ilk bilgi kaynağı olan başlığın belirlenmesine bir standart getirilmesi amacıyla bu araştırma daha geniş evren ve örneklemde yapılmalıdır. Böyle bir araştırmanın sonucu özellikle bütün üniversiteler tarafından dikkate alınmalıdır.

\section{Kaynakça}

Coşkun, E. (2005). Illköğretim öğrencilerinin öyküleyici anlatımlarında bağdaşıklık, tutarlıık ve metin elementleri. Gazi Üniversitesi Eğitim Bilimleri Enstitüsü Yayımlanmamış Doktora Tezi, Ankara.

Çetinkaya, G. (2010). Türkçe metinlerin okunabilirlik düzeylerinin tanımlanması ve sınıflandırılması. Ankara Üniversitesi Sosyal Bilimler Enstitüsü Yayımlanmamış Doktora Tezi, Ankara.

Day, R. A. (2000). Bilimsel bir makale nasıl yazılır ve yayımlanır? Ankara: TÜBiTAK.

Deniz, K. (2000). Yazılı anlatım becerileri bakımından köy ve kent beşinci sınıf öğrencilerinin durumu. Çanakkale Onsekiz Mart Üniversitesi Sosyal Bilimler Enstitüsü Yayınlanmamış Yüksek Lisans Tezi, Çanakkale.

Durukan, E. (2014). Metinlerin okunabilirlik düzeyleri ile öğrencilerin okuma becerileri arasındaki ilişki. Ana Dili Eğitimi Dergisi, 2(3), s. 68-76.

Günay, D. (2001). Metin bilgisi. İstanbul: Multilingual Yayınları.

Karasar, N. (2008). Bilimsel araştırma yöntemi. Ankara: Nobel Yayıncılık.

Karatay, H., Bolat, K.K. ve Güngör, H. (2013). Türkçe ders kitaplarındaki metinlerin okunabilirlik ve anlaşılabilirliği. International Journal of Socials cience. 6(6), s. 603-623.

Korkmaz, Z. (2007). Gramer terimleri sözlüğü. Ankara: Türk Dil Kurumu Yayınları.

Sevim, O. ve Erem, N. (2012). Türkçe eğitimi alanındaki yüksek lisans tezlerinin başlıklarına ve özetlerine eleştirel bir bakış. Uluslararası Türkşe Edebiyat Kültür Eğitim Dergisi. Sayı: 1/3. s. 174-186.

Tansel, F. A. (1978). İyi ve doğru yazma usûlleri III. İstanbul: Kubbealtı Neşriyatı.

Temur, T. (2003). Okunabilirlik (readability) kavramı. TÜBAR-XIII, s. 169-180.

TÜBITAK, Türkiye Bilimsel ve Teknolojik Araştırma Kurumu Araştırma Destek Programları Başkanlığı Tarafından Yürütülen Programlara Iliş̧kin Yönetmelik, 06.05.2015 tarihinde http://www.tubitak.gov.tr/ sites/default/ files/yonetmelik_iii_1-vers.1.pdf'den erişildi.

Yıldırım, A. ve Şimşek, H. (2011). Sosyal bilimlerde nitel araştırma yöntemleri. Ankara: Seçkin Yayıncılık.

Yıldız, C. (2000). Yazılı basında metin ve manşet, İstanbul: Teknik Yayınları. 